\title{
Projections of changes in heavy precipitation in the northern foothills of the Tatra Mountains
}

\author{
Iwona Pińskwar, Zbigniew W. Kundzewicz ${ }^{1}$, Adam Choryński \\ The Institute for Agricultural and Forest Environment of Polish Academy of Sciences, Bukowska 19, 60-809 Poznań, \\ Poland, e-mail: iwona.pinskwar@isrl.poznan.pl
}

\begin{abstract}
Heavy and/or long-lasting precipitation events in the Tatra Mountains and their northern foothills may cause floods that propagate downstream in the Vistula River and inundate large areas of Poland. In a warmer climate, future precipitation extremes could be higher than they are today, hence the flood risk potential is likely to grow. Therefore, assessment of these future changes and adaptation to changes in flood risk are of considerable interest and importance. In this study, seven global climate models were used to get insight into a range of changes in the characteristics of mean and heavy precipitation: this was done for two climate scenarios - A1B and A2 of the SRES family. With the help of the so-called delta-change method and based on responses from global climate models, projections were made for 11 precipitation stations in the region. Analyses were made of various indices, such as annual totals, maximum 24 h, 5-day; 10-day, monthly maximum sums of precipitation and also numbers of days with intense precipitation equal or above the thresholds of 30 and $50 \mathrm{~mm}$ per day. It was found that all GCM models under examination projected an increase in mean annual precipitation totals as well as in heavy precipitation in the future time horizon studied here (2080-2100).
\end{abstract}

Key words: heavy precipitation, climate models, projections, delta-change method, Poland

Submitted 24 October 2016, revised 22 December 2016, accepted 15 February 2017

\section{Introduction}

Floods are the most destructive natural hazard in Poland and most of the flood damage in the country usually occurs in the basins of two large rivers: the Upper Vistula and the Upper Odra. Abundant rainfall in the Upper Vistula basin, especially in the mountainous catchments of right-hand tributaries to the Vistula - the Dunajec, Raba, Wisłoka and Skawa rives- leads to violent and highly erosive flood events. Since the beginning of the $20^{\text {th }}$ century, destructive floods occurred most frequently in July (in 1903, 1934, 1960, 1970, 1997, 2001), but also in other months between May and September (e.g. in May and June 2010).

The Tatra Mountains (in Polish Tatry), located in southern Poland and northern Slovakia, are the highest range (with peaks up to $2499 \mathrm{~m}$ - Rysy in Poland and $2655 \mathrm{~m}$ - Gerlach in Slovakia) of the Carpathian Mountains. The Tatra Mountains and their northern foothills belong to the drainage basin of the largest Polish river - the Vistula. Precipitation recorded in the region is the highest in Poland and largely contributes to the generation of flood risk downstream as well (Niedźwiedź et al. 2015). Therefore, the assessment of future changes in intense precipitation is very important and much needed. Every increase in magnitude, duration, and frequency of extreme precipitation may increase climate-related flood hazards. About 40\% of annual precipitation in the region (35\% at Kasprowy Wierch and $43 \%$ in Zakopane) falls in summer, while in winter, on average, this proportion is much smaller $(20 \%$ at Kasprowy Wierch and 13\% in Zakopane), cf. Łupikasza et al. (2016). The mean annual precipitation at Kasprowy Wierch (1991 m a.s.1.) for the period 1951-2013 was $1752 \mathrm{~mm}$, with the record-high annual maximum precipitation at this station recorded as $2599 \mathrm{~mm}$ in 2001. Even higher annual precipitation values were recorded in 2001 at two other stations: $2628 \mathrm{~mm}$ at Hala Gąsienicowa and $2770 \mathrm{~mm}$ at Dolina Pięciu Stawów (Kundzewicz et al. 2014). Such large values resulted from very intense precipitation in July of 2001. Monthly values for this month were the highest for nine stations of interest (with available data) for the whole researched period, i.e. for Kasprowy Wierch $651 \mathrm{~mm}$, Hala Gąsienicowa $743 \mathrm{~mm}$, Morskie Oko 617 mm, Zakopane 439 mm, Witów 436 mm, Poronin $505 \mathrm{~mm}$, Białka Tatrzańska $313 \mathrm{~mm}$, Szaflary $326 \mathrm{~mm}$ and Jabłonka $439 \mathrm{~mm}$. Indeed, July 2001 was extreme in Poland as far as heavy precipitation is concerned. This was the case not only in mountainous regions, but also in remote places located far away, near to the mouth of the Vistula River. In Gdańsk, high precipitation caused destructive urban flash floods in 2001 (cf., Majewski

\footnotetext{
${ }^{1}$ Senior Scientist in the Potsdam Institute for Climate Impact Research (PIK), Potsdam, Germany.
} 
2016) and also more recently. Furthermore, in the next year with large flooding, i.e. in 2010, the highest ever (i.e. in the interval for which instrumental data are available) values of the annual sum of precipitation occurred at five lower-located stations, i.e. in Zakopane (1646 mm), Poronin (1562 mm), Witów (1518 mm); Szaflary (1150 $\mathrm{mm}$ ) and Jabłonka (964 mm). For the other four stations analysed in this paper, one of the highest overall values was measured at this time. The year 2010 was very humid - this was especially due to the extremely high precipitation total during May, with the highest observed monthly values for nine stations examined in this paper (Kasprowy Wierch $430 \mathrm{~mm}$, Hala Gąsienicowa $504 \mathrm{~mm}$, Morskie Oko 462 mm, Zakopane 375 mm, Witów 371 mm, Poronin $355 \mathrm{~mm}$, Białka Tatrzańska $223 \mathrm{~mm}$, Szaflary 236 $\mathrm{mm}$, Jabłonka $255 \mathrm{~mm}$ ). A monthly precipitation record was also observed in the Odra River basin in May 2010, at Istebna Stecówka (Szalińska et al. 2014).

This study presents projections of the intensity of annual and precipitation extremes for 11 meteorological stations located in the area of the northern foothills of the Tatra Mountains in Poland for the time horizon 20812100. A range of heavy precipitation indices, which are defined in Table 1, are examined. The calculation is based on the application of the so-called delta-change method (Van Pelt et al. 2012; Pińskwar et al. 2016) to results of the simulation of future changes in heavy precipitation by global climate models. This method was applied to each station individually. Particular attention was paid to the assessment of future changes in precipitation during the warm part of the year (April-September), especially precipitation occurring within the summer period, when floods in the region are most frequently generated.

\section{Data and study site}

This study makes use of seven General Circulation Models (GCMs) simulations (for A1B and A2 scenarios of the SRES family, cf. Nakicenovic et al. 2000), stemming from the KNMI Climate Explorer (http://climexp. knmi.nl), for the area between $49^{\circ}-49.5^{\circ} \mathrm{N}$ latitude and $19.5^{\circ}-20.5^{\circ} \mathrm{E}$ longitude. Model outputs were generated for halfway grid points for this area. Simulations with the help of these models are available for the last two decades of the $21^{\text {st }}$ century, i.e. 2081-2100, as well as for the past interval, 1961-1990. The global model BCCR BCM2 (Bergen Climate Model, BCM, version 2; Bjerknes Centre for Climate Research, BCCR, University of Bergen, Norway) has a resolution of $2.8^{\circ}$ of latitude by $2.8^{\circ}$ of longitude (for a slightly different future time horizon, 2081-2099 and scenario A2). CCCMA CGCM3.1t63 is the third version of the Canadian Centre for Climate Modelling and Analysis (CCCma) Coupled Global Climate Model (CGCM3) with a resolution of $2.8 \times 2.8^{\circ}$ (scenario A1B). GFDL's CM2 Global Coupled Climate Models were developed at NOAA's Geophysical Fluid Dynamics Laboratory (GFDL). Two versions of the coupled model called CM2.0 (scenarios: A1B and A2) and CM2.1 (A2 scenario) have a resolution of $2 \times 2.5^{\circ}$. The MIROC3.2 HiRes Global Model (Center for Climate System Research/National Institute for Environment/Frontier Research Center for Global Change, Japan) has a resolution of $1.13 \times 1.13^{\circ}$ (scenario A1B). The HadCM3 (Hadley Centre Coupled Model, version 3) is a coupled Atmosphere-Ocean General Circulation model (AOGCM) developed at the Hadley Centre in the United Kingdom. The resolution of this model is $2.5 \times 3.75^{\circ}$ (scenario A2).

Table 1. Definitions of the mean and heavy precipitation indices used in this paper

\begin{tabular}{|c|c|c|}
\hline \multicolumn{2}{|r|}{ Index } & Definition \\
\hline 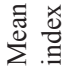 & Annual precipitation $[\mathrm{mm}]$ & $\begin{array}{l}\text { The sum of precipitation calculated for the whole calendar year } \\
\text { (January to December) }\end{array}$ \\
\hline \multirow{6}{*}{ 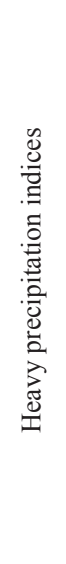 } & Maximum $24 \mathrm{~h}$ precipitation [mm] & $\begin{array}{l}\text { The highest amount of 1-day precipitation calculated for the whole calendar year } \\
\text { (January to December) }\end{array}$ \\
\hline & Maximum 5-day precipitation [mm] & $\begin{array}{l}\text { The highest amount of 5-day precipitation calculated for the warm period } \\
\text { (April-September) }\end{array}$ \\
\hline & Maximum 10-day precipitation [mm] & $\begin{array}{l}\text { The highest amount of 10-day precipitation calculated for the warm period } \\
\text { (April-September) }\end{array}$ \\
\hline & Monthly maximum sum of precipitation [mm] & $\begin{array}{l}\text { The highest amount of monthly precipitation calculated for whole calendar year } \\
\text { (January-December) }\end{array}$ \\
\hline & $\begin{array}{l}\text { Number of days with intense precipitation equal } \\
\text { or above the threshold of } 30 \mathrm{~mm} \text { per day [day] }\end{array}$ & $\begin{array}{l}\text { The number of days where the amount of daily precipitation is equal or above } \\
30 \mathrm{~mm} \text { calculated for the warm period (April-September) }\end{array}$ \\
\hline & $\begin{array}{l}\text { Number of days with intense precipitation equal } \\
\text { or above the threshold of } 50 \mathrm{~mm} \text { per day [day] }\end{array}$ & $\begin{array}{l}\text { The number of days where the amount of daily precipitation is equal or above } \\
50 \mathrm{~mm} \text { calculated for the warm period (April-September) }\end{array}$ \\
\hline
\end{tabular}


Analysing simulations from an ensemble of various models allows uncertainty to be taken into account. Hence, the results from climate models are used to produce projections of future precipitation indices by the modification of observed precipitation data in the control period (19611990) from 11 meteorological stations in the Upper Vistula River basin, situated in the Tatra Mountains and their northern foothills, in basins of the rivers: Czarny Dunajec, Biały Dunajec, and Białka. For one station, Hala Ornak, data extend from 1970 to 1990; even though the period is shorter, this station is very important from the point of view of the impact of precipitation on the formation of floods, so it is retained in this study. The Czarny Dunajec River is considered the headwater of the Dunajec, one of the largest rivers of the Polish Carpathians and a righthand tributary to the Vistula. The Czarny Dunajec rises at $1540 \mathrm{~m}$ a.s.l. in the Western Tatra massif as the Chochołowski Stream that collects water from Jarząbczy Wierch (2137 $\mathrm{m}$ a.s.1.), Wołowiec (2064 m a.s.1.) and Rakon (1879 m a.s.l.) (Czarnecka 1983). The Czarny Dunajec joins with the Biały Dunajec in the town of Nowy Targ at the altitude of $578 \mathrm{~m}$. The Stream Małołącki (lower Cicha Woda and Zakopianka rivers) is the headwater of the Biały Dunajec. It rises from the peaks of the Czerwone Wierchy massif, at the elevation about $2000 \mathrm{~m}$ a.s.1. The Biała Woda Stream gives rise to the Białka River whose source are situated in granite parts of the High Tatra massif (Czarnecka 1983). Jabłonka station is located in the Czarna Orawa basin, belonging to the basin of the Danube River, which drains into the Black Sea. Precipitation from Jabłonka (the Danube River catchment) does not play a role in forming floods on the Vistula River basin, but it enriches our knowledge about the intensity and amount of precipitation on the analysed area. Data from this station were used due to the limited availability of data in the studied basins. The location of this station is close to the Dunajec River basin, and this enriches our knowledge of spatial distribution of precipitation (Fig. 1). According to
Starkel (1991), this region is characterised by high values of excess water and accelerated outflow. In the north of this area, mountainous valleys are situated where water retention takes place. The 11 analysed stations are: Kasprowy Wierch, Hala Gąsienicowa, Morskie Oko, Hala Ornak (with a shorter period of available records: 1970-1990), Kuźnice, Zakopane, Witów, Poronin, Białka Tatrzańska, Szaflary - all in the Vistula River basin, and Jabłonka in the Danube River basin. The location of these stations is illustrated in Fig. 1.

\section{Results}

Łupikasza et al. (2016) analysed the observed changes in climate (temperature and precipitation) and found that, for nearly all the examined stations, precipitation totals in the warmer period (1991-2011/2013) were higher than in the earlier, cooler, period (1961-1990). However, most of the observed changes in precipitation between 19512015 were not statistically significant, at the level of 0,05. Precipitation showed strong and irregular natural variability. Niedźwiedź, Łupikasza (2016) analysed the observed changes in atmospheric circulation patterns, noting a correlation between long-term courses of circulation indices and high precipitation, for Nc and NEc circulation indices. However, most increasing trends in circulation indices favouring the occurrence of high precipitation were not statistically significant.

Table 2 illustrates the maximum 24-h precipitation and 5-day precipitation sums at each of the examined stations and the year of occurrence of this maximum precipitation within the available period of observations. Both 24-h and 5-day precipitation totals are of importance for flood hazard. According to the observed data, most of the 24-h maximum precipitation, as well as maximum 5-day precipitation, appeared in the examined control period: 1961-1990. Only in five cases did the maximum values of these indices occur later - in 1997 (the year with a large

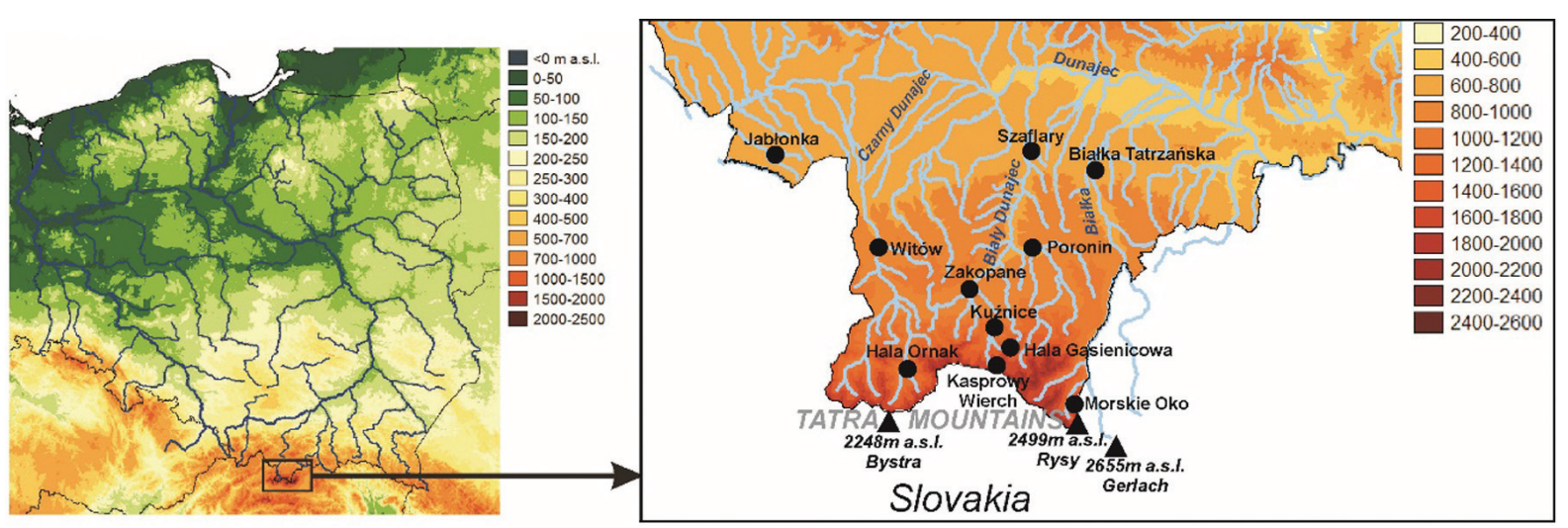

Fig. 1. Location of the studied area in Poland and location of the meteorological stations in the area of the northern foothills of the Tatra Mountains 
Table 2. The maximum 24-h and 5-day precipitation and the year of occurrence, for the available period of observations for 11 meteorological stations in the Tatra Mountains and their northern foothills

\begin{tabular}{|l|c|c|c|c|c|}
\hline Station & $\begin{array}{c}\text { Elevation } \\
{[\mathrm{m} \text { a.s.1. }]}\end{array}$ & $\begin{array}{c}\text { Max 24-h } \\
\text { precipitation } \\
{[\mathrm{mm}]}\end{array}$ & $\begin{array}{c}\text { Year of } \\
\text { occurrence }\end{array}$ & $\begin{array}{c}\text { Max 5-day } \\
\text { precipitation } \\
{[\mathrm{mm}]}\end{array}$ & $\begin{array}{c}\text { Year of } \\
\text { occurrence }\end{array}$ \\
\hline Kasprowy Wierch & 1991 & 232,0 & 1973 & 388,7 & 1980 \\
\hline Hala Gąsienicowa & 1520 & 300,0 & 1973 & 425,2 & 1980 \\
\hline Morskie Oko & 1408 & 168,4 & 1958 & 296,3 & 1970 \\
\hline Hala Ornak & 1109 & 205,3 & 1973 & 343,6 & 1980 \\
\hline Kuźnice & 1024 & 172,7 & 1973 & 263,5 & 1980 \\
\hline Zakopane & 857 & 138,7 & 1970,1973 & 235,9 & 1972 \\
\hline Witów & 835 & 111,3 & 1970 & 200,4 & 1972 \\
\hline Poronin & 773 & 156,1 & 1997 & 248,2 & 1997 \\
\hline Białka Tatrzańska & 700 & 112,0 & 1997 & 188,3 & 1997 \\
\hline Szaflary & 655 & 103,4 & 1970 & 179,1 & 1997 \\
\hline Jabłonka & 635 & 70,1 & 2007 & 144,7 & 1972 \\
\hline
\end{tabular}

flood) and in 2007. The 24-h maxima occurred at four stations in 1973, three in 1970 and two in 1997, while the 5-d maxima occurred at four stations in 1980, and three in 1972 and 1995. The value of $300 \mathrm{~mm}$ recorded on 30 June 1973 at Hala Gąsienicowa station is the highest 24-h precipitation sum ever observed in Poland. Łupikasza et al. (2016) found upward trends in maximum 24-h and 5-d precipitation sums as well as in the frequency of days with precipitation greater than or equal to $50 \mathrm{~mm}$ at Kasprowy Wierch and Zakopane stations.

The time intervals for which data are available were: 19512013 for Kasprowy Wierch and Zakopane, 1951-2011 for Hala Gąsienicowa, Poronin, Białka Tatrzańska, Szaflary, Morskie Oko, 1954-2011 for Witów, 1955-2011 for Jabłońka, 1954-1996 for Kuźnice, and 1970-2011 for Hala Ornak.

Climate models have greater difficulty in simulating precipitation as opposed to temperature because of the complexity of the phenomenon involving the sub-grid scale features, such as topography or land use, that are often inadequate for assessing the correct location and intensity of precipitation. This is especially noticeable for such a complex and difficult area as the
Tatra Mountains and their northern foothills. For a comparison of observed and modelled precipitation in the control period, 1961-1990, see Pińskwar et al. (2016). Although there is some disagreement as to the range of the changes, almost all the GCMs agree on the direction of change; i.e. an increase in mean and extreme precipitation.

In general, the analysed GCM models project an increase in annual precipitation for the studied area. The future median is likely to be higher for stations located above $1000 \mathrm{~m}$ a.s.l. For stations at lower elevations, GCMs project a smaller increase, or even a decrease, for stations: Białka Tatrzańska, Szaflary and Jabłonka. However, the future level of the 75 percentile and the proxy for the extreme value (95 percentile) of annual precipitation are projected to be higher than those observed in 1961-1990 for every station. Figure 2 shows box plots with observed annual precipitation for the interval 19611990 and projected annual precipitation for GCMs for listed stations.

Figure 3 shows the return period plots (under the assumption of Gumbel distribution) of the maximum daily precipitation for the future projections obtained from the GCMs used in this study for 11 meteorological stations,
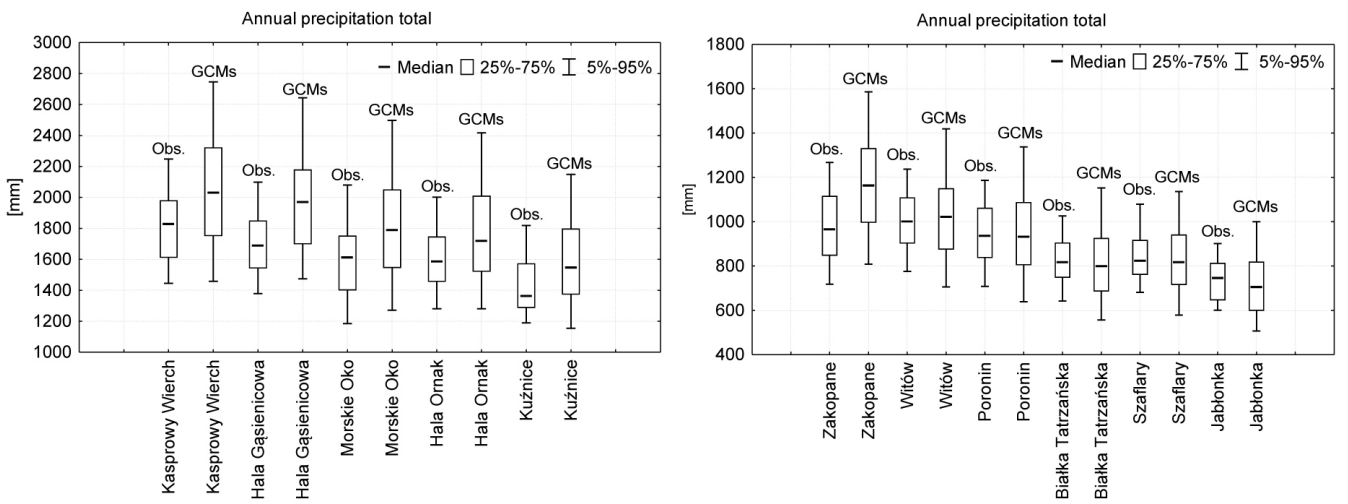

Fig. 2. Observed annual sum of precipitation for the control interval 1961-1990 and projected annual sum of precipitation for GCMs (2081-2100) for stations located at elevation above $1000 \mathrm{~m}$ a.s.l. (left) and stations situated below $1000 \mathrm{~m}$ a.s.l. (right) 

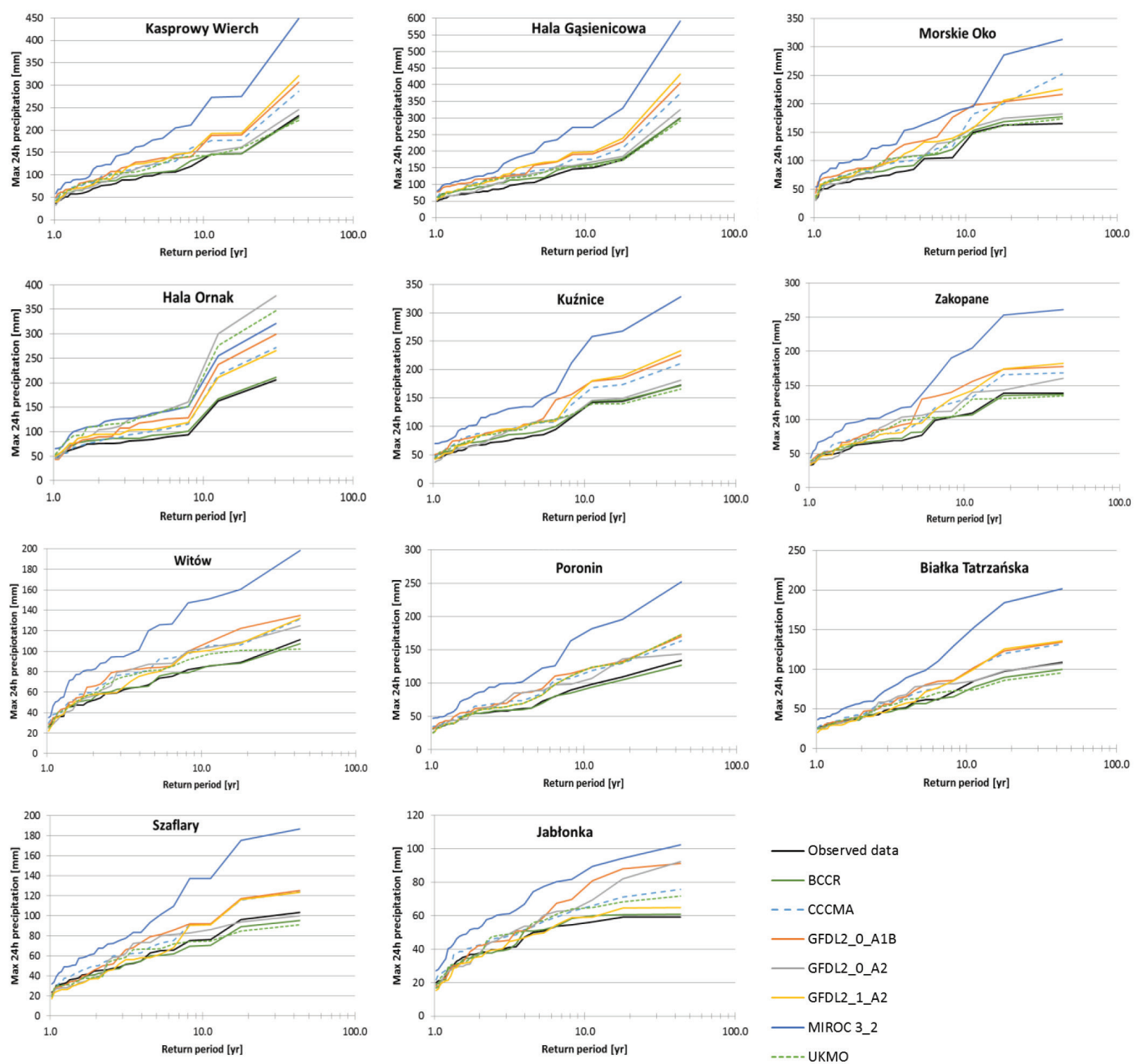

Fig. 3. The return period plots (Gumbel distribution) calculated for 30-year time series (21-year for Hala Ornak) of the maximum daily precipitation for observed data (1961-1990) and the GCMs (2081-2100) for 11 meteorological stations situated on the northern foothills of the Tatra Mountains

and also a comparison with the observed data. Distinctly higher values correspond to the MIROC model. Most GCM models suggest an increase in maximum $24 \mathrm{~h}$ precipitation.

Figure 4 presents box plots with observed maximum 5-day precipitation for the reference period 1961-1990 and the projected value of this index for GCMs for particular stations. For all stations, increases in the median, the 75 percentile and also the extreme values are projected. The future median of maximum 5-day precipitation for stations located high up (above $1000 \mathrm{~m}$ a.s.1.), as well as for Zakopane, could be similar to the level of 75 percentile for the control period 1961-1990.

A similar situation can be observed for maximum 10 day precipitation for the warm season (April-September). The changes in median for higher-located stations are pro- jected to be greater than those observed in 1961-1990. The level of the present 75 percentile is similar to that of the median of the projection for the future (2081-2100). In the case of lower-placed meteorological stations, the median of maximum 10-day precipitation could be on a similar level to the one observed in the 20th century. The future 75 percentile and extreme value (95 percentile) of this index are likely to be higher for all stations (Fig. 5).

The GCM simulations show an increase in the median as well as in 75 percentile and extreme value (95 percentile) for the maximum monthly sum of precipitation in the warm season (April-September) for higher-located stations and for Zakopane. For other studied stations, the increases of this index could be lower. Figure 6 presents the observed ranges for the maximum monthly sum of precipitation and projected changes, according to GCMs. 

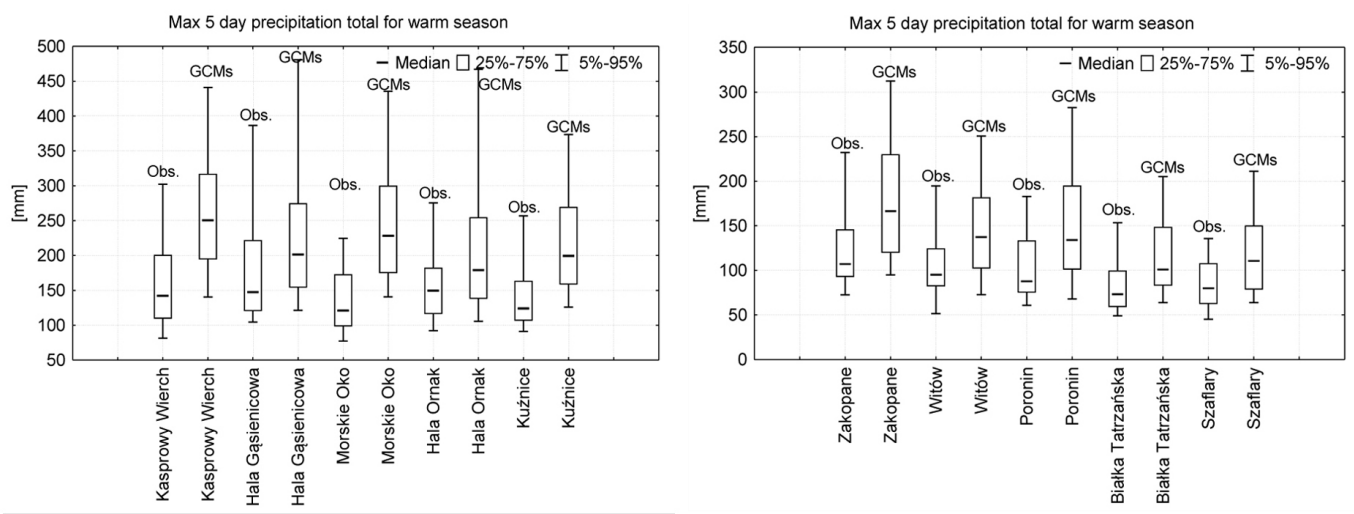

Fig. 4. Observed maximum 5-day precipitation for the reference interval 1961-1990 and projected maximum 5-day precipitation for GCMs (2081-2100) for stations located at the elevation above $1000 \mathrm{~m}$ a.s.l. (left) and below $1000 \mathrm{~m}$ a.s.l. (right)
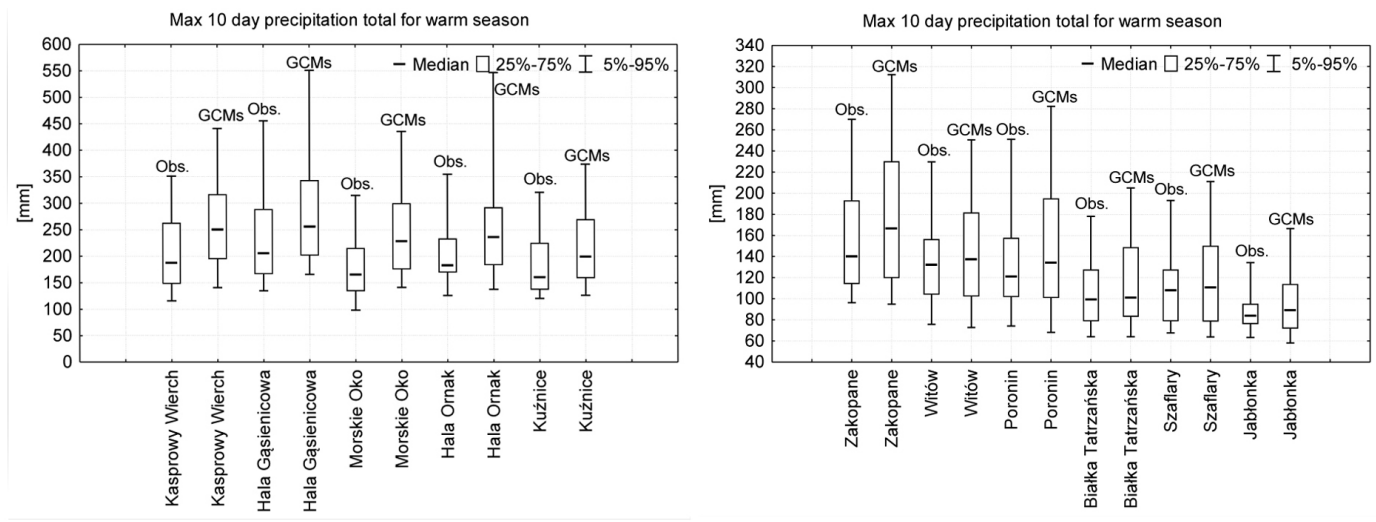

Fig. 5. Observed maximum 10-day precipitation for 1961-1990 and projected maximum 10-day precipitation for GCMs (2081-2100) for stations located at the elevation above $1000 \mathrm{~m}$ a.s.l. (left) and below $1000 \mathrm{~m}$ a.s.l. (right)
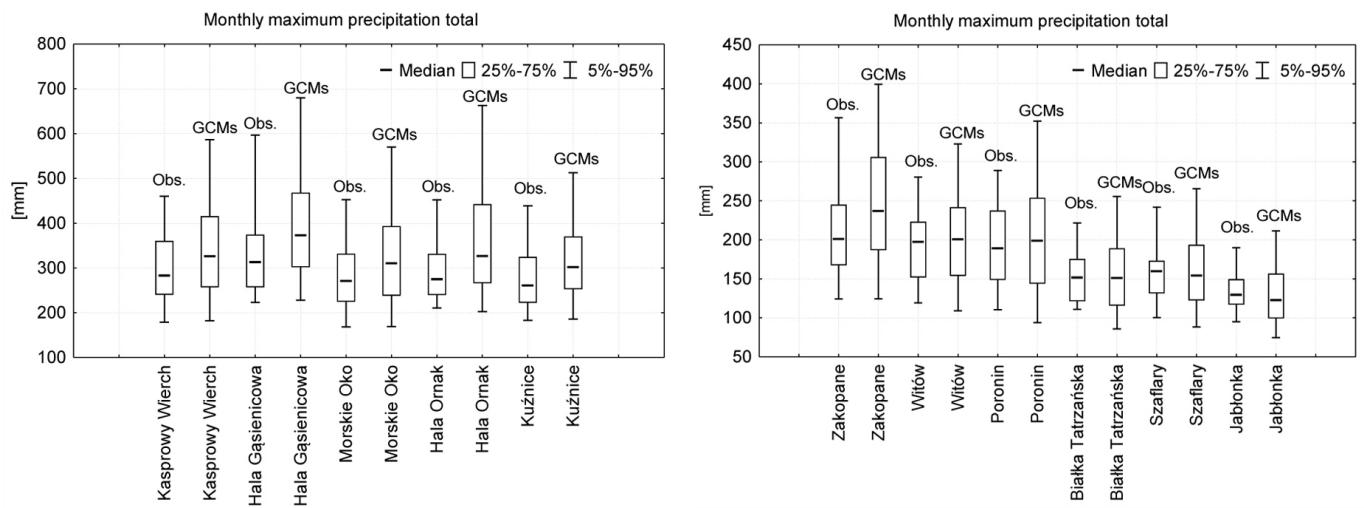

Fig. 6. Observed maximum monthly sum of precipitation for 1961-1990 and projected value for GCMs (2081-2100) at stations located at the elevation above $1000 \mathrm{~m}$ a.s.l. (left) and below $1000 \mathrm{~m}$ a.s.l. (right)

Similar behaviour for projections of increases in the number of days with intense precipitation (greater than or equal to 30 or $50 \mathrm{~mm}$ ) during the warm season can be observed (Fig. 7). For the stations above $1000 \mathrm{~m}$ a.s.l. for both thresholds (i.e. 30 or $50 \mathrm{~mm}$ ), global models show an increase in median and in higher percentiles (75 and 95). For other stations, the number of days with intense precipitation (30 $\mathrm{mm}$ per day and above) may increase slightly and the number of days with very intense precipitation (50 $\mathrm{mm}$ per day and above) is likely to stay at the same level. In the future, the occurrence of days with intense precipitation (above 30 or $50 \mathrm{~mm}$ ) may be very rare. Projections show an increase in precipitation intensity rather than in frequency.

\section{Discussion and conclusions}

This study allows an insight into projected future changes in annual precipitation as well as in intense and extreme precipitation indices in the Tatra Mountains and their northern foothills. The use of seven global climate models for two SRES climate scenarios, A1B and A2, 

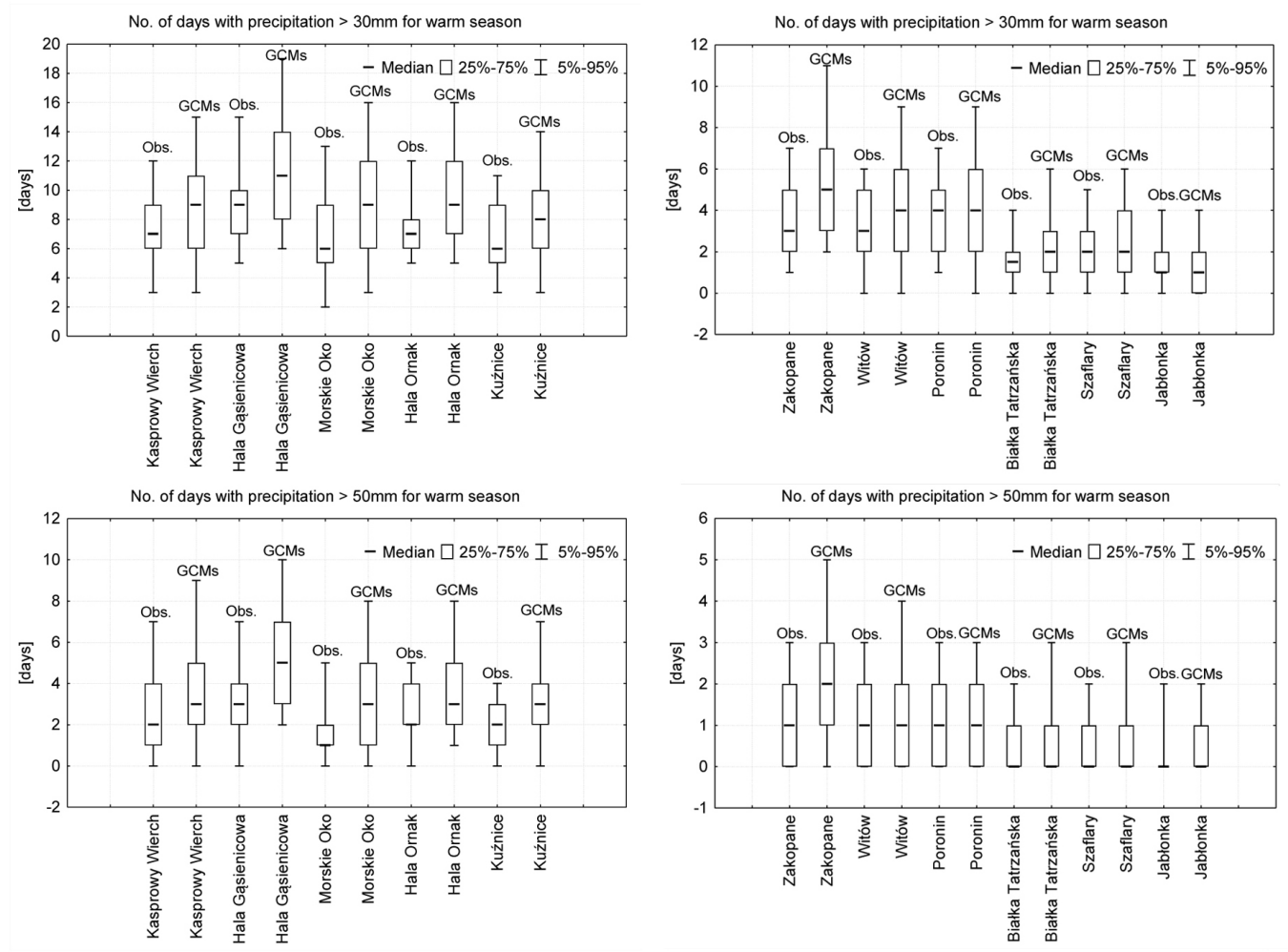

Fig. 7. Number of days with $24 \mathrm{~h}$ precipitation equal to or greater than the threshold of: $30 \mathrm{~mm}$ (top) and $50 \mathrm{~mm}$ (bottom) for the warm season, observed in 1961-1990 and projected for 2081-2100, for stations located at the elevation above $1000 \mathrm{~m}$ a.s.1. (left) and below $1000 \mathrm{~m}$ a.s.l. (right)

made it possible to obtain a range of changes in precipitation at 11 stations for the last decades of the $21^{\text {st }}$ century.

Information about changes in precipitation extremes is very important for climate change adaptation and flood risk reduction (Zhang et al. 2013). The use of multiple climate model simulations covers a range of plausible changes in extremes.

Models in this study belong to the generation of GCMs used in the Coupled Model Intercomparison Project Phase 3 (CMIP3) in support of the Intergovernmental Panel on Climate Change (IPCC) Fourth Assessment Report (AR4) (Kharin et al. 2007). In the most recent generation of global climate models participating in the Coupled Model Intercomparison Project Phase 5 (CMIP5), the new radiative forcing scenarios, called Representative Concentration Pathways (RCPs, Moss et al. 2010), are employed. However, apart from the different forcing scenarios in the CMIP5 protocol, the performance of the CMIP5 multi-model ensemble in simulating precipitation extremes is comparable to that in the CMIP3 ensemble (Kharin et al. 2013).

All the GCMs under examination project an increase in mean annual precipitation totals as well as in various measures of heavy precipitation in a future time horizon, 2081-2100. However, the changes in mean precipitation were not as pronounced as for extreme indices, such as maximum 24 h, 5-day; 10-day, and monthly precipitation totals, and also for the number of days with intense precipitation (greater than or equal to 30 or $50 \mathrm{~mm}$ ). An increase is projected especially for stations located above $1000 \mathrm{~m}$ a.s.1. For most stations located in the area of the northern foothills of the Tatra Mountains, the increase in precipitation may result in more severe flash floods and landslides in small catchments and may generate flood events in basins of the mountainous right-hand tributaries of the River Vistula (such as the Dunajec River).

Our findings are in qualitative agreement with those general, large-scale, results of Seneviratne et al. (2012), who examined the projections of changes in the return period of the late $20^{\text {th }}$ century (1981-2000) for 20-year annual maximum 24-h precipitation. The 20-year return period for the area of Central Europe for the reference interval is likely to become more frequent, e.g. a 1-in-10 to 1 -in-15 year event by the end of $21^{\text {st }}$ century (the median for multiple models).

Every increase in extreme precipitation may contribute to more severe floods in the future. However, recent studies indicate that the projection of precipitation extremes is associated with various uncertainties related to emission scenarios of greenhouse gases, GCMs, and statistical downscaling methods, as well as by the natural variability of the climate. Nevertheless, records of precipitation dur- 
ing the latest large floods in the studied region, i.e. in 2001 and 2010, also show that the observed values of maximum monthly sums of precipitation reached new heights.

\section{Acknowledgments}

This study was carried out within the FLORIST (Flood risk on the northern foothills of the Tatra Mountains) project, supported by a grant from the Swiss Government through the Swiss Contribution to the enlarged European Union (PSPB No. 153/2010). The authors kindly acknowledge receipt of meteorological data from the Polish National Hydrometeorological Service, IMGW-PIB.

Bibliography

Czarnecka H. (ed.), 1983, Atlas of hydrographic division of Poland, (in Polish), IMGW, Warszawa, 924 pp.

IPCC, 2007, Climate change 2007: Synthesis Report, Contribution of Working Groups I, II and III to the Fourth Assessment Report of the Intergovernmental Panel on Climate Change, R.K. Pachauri, A. Reisinger (eds.), IPCC, Geneva, 104 pp.

IPCC, 2012, Managing the risks of extreme events and disasters to advance climate change adaptation. A special report of working groups I and II of the intergovernmental panel on climate change, C.B. Field, V. Barros, T.F. Stocker, D. Qin, D. Dokken, K.L. Ebi, M.D. Mastrandrea, K.J. Mach, G.-K. Plattner, S.K. Allen, M. Tignor, P.M. Midgley (eds.), Cambridge University Press, Cambridge, UK, New York, 582 pp.

Kharin V.V., Zwiers F.W., Zhang X., Hegerl G.C., 2007, Changes in temperature and precipitation extremes in the IPCC ensemble of global coupled model simulations, Journal of Climate, 20, 1419-1444, DOI: 10.1175/JCLI4066.1

Kharin V.V., Zwiers F.W., Zhang X., Wehner M., 2013, Changes in temperature and precipitation extremes in the CMIP5 ensemble, Climatic Change, 119 (2), 345-357, DOI: 10.1007/ s10584-013-0705-8

Kundzewicz Z.W., Stoffel M., Kaczka R.J., Wyżga B., Niedźwiedź T., Pińskwar I., Ruiz-Villanueva V., Łupikasza E., Czajka B., Ballesteros-Canovas J.A., Małarzewski Ł., Choryński A., Janecka K., Mikuś P., 2014, Floods at the Northern Foothills of the Tatra Mountains - a Polish-Swiss research project, Acta Geophysica, 62 (3), 620-641, DOI: 10.2478/s11600-013-0192-3

Łupikasza E., Niedźwiedź T., Pińskwar I., Ruiz-Villanueva V., Kundzewicz Z.W., 2016, Observed changes in temperature and precipitation and relationship between them, in the Upper Vistula Basin, [in:] Flood risk in the upper Vistula basin, Z.W. Kundzewicz, M. Stoffel, T. Niedźwiedź, B. Wyżga (eds.), Springer International Publishing, 155-187

Majewski W., 2016, Urban flash flood in Gdańsk-2001. Case study, Meteorology, Hydrology and Water Management, 4 (2), 41-49
Moss R.H., Edmonds J.A., Hibbard K.A., Manning M.R., Rose S.K., van Vuuren D.P., Carter T.R., Emori S., Kainuma M., Kram T., Meehl G.A., Mitchell J.F.B., Nakicenovic N., Riahi K., Smith S.J., Stouffer R.J., Thomson A.M., Weyant J.P., Wilbanks T.J., 2010, The next generation of scenarios for climate change research and assessment, Nature, 463, 747-756, DOI: 10.1038 /nature 08823

Nakicenovic N., Alcamo J., Davis G., de Vries B., Fenhann J., Gaffin S., Gregory K., Grübler A., Jung T.Y., Kram T., La Rovere E.L., Michaelis L., Mori S., Morita T., Pepper W., Pitcher H., Price L., Riahi K., Roehrl A., Rogner H.-H., Sankovski A., Schlesinger M., Shukla P., Smith S., Swart R., van Rooijen S., Victor N., Dadi Z., 2000, IPCC special report on emissions scenarios, Cambridge University Press, Cambridge, New York, 599 pp.

Niedźwiedź T., Łupikasza E., Pińskwar I., Kundzewicz Z.W., Stoffel M., Małarzewski Ł., 2015, Variability of heavy rainfall events and related synoptic situations causing floods at the northern foothills of the Tatra Mountains, Theoretical and Applied Climatology, 119 (1), 273-284, DOI: 10.1007/ s00704-014-1108-0

Niedźwiedź T., Łupikasza E., 2016, Change in atmospheric circulation patterns, [in:] Flood risk in the upper Vistula basin. Z.W. Kundzewicz, M. Stoffel, T. Niedźwiedź, B. Wyżga (eds.), Springer International Publishing, 189-208

Pińskwar I., Choryński A., Kundzewicz Z.W., Ruiz-Villanueva V., 2016, Projections of precipitation in the northern foothills of the Tatra Mountains, [in:] Flood risk in the upper Vistula basin. Z.W. Kundzewicz, M. Stoffel, T. Niedźwiedź, B. Wyżga (eds.), Springer International Publishing, 311-329

Seneviratne S.I., Nicholls N., Easterling D., Goodess C.M., Kanae S., Kossin J., Luo Y., Marengo J., McInnes K., Rahimi M., Reichstein M., Sorteberg A., Vera C., Zhang X., 2012, Changes in climate extremes and their impacts on the natural physical environment, [in:] Managing the risks of extreme events and disasters to advance climate change adaptation. A special report of working groups I and II of the Intergovernmental Panel on Climate Change (IPCC), C.B. Field, V. Barros, T.F. Stocker, D. Qin, D.J. Dokken, K.L. Ebi, M.D. Mastrandrea, K.J. Mach, G.-K. Plattner, S.K. Allen, M. Tignor, P.M. Midgley (eds.), Cambridge University Press, Cambridge, New York, 109-123

Starkel L., 1991, Relief of the terrain, (in Polish), [in:] Upper Vistula Basin. Part I, I. Dynowska, M. Maciejewski (eds.), Państwowe Wydawnictwo Naukowe, Warszawa-Kraków, $42-54$

Szalińska W., Otop I., Tokarczyk T., 2014, Precipitation extremes during flooding in the Odra River Basin in May-June 2010, Meteorology, Hydrology and Water Management, 2 (1), 13-21 Van Pelt S.C., Beersma J.J., Buishand T.A., Van den Hurk B.J.J.M., Kabat P., 2012, Future changes in extreme pre- 
cipitation in the Rhine basin based on global and regional climate model simulations, Hydrology and Earth Systems Science, 16, 4517-4530, DOI: 10.5194/hess-16-4517-2012

Zhang X., Hegerl G.C., Seneviratne S.I., Stewart R., Zwiers F.W., Alexander L.V., 2013, WCRP grand challenge: un- derstanding and predicting weather and climate extremes, 10 pp., available at http://www.clivar.org/sites/default/files/ documents/pan-clivar/pan_clivar_reports/WCRP_Extremes. pdf (data access 30.03.2017) 